Review

\title{
Analytical Proof of Origin for Raw Materials
}

\author{
Frank Melcher ${ }^{1}$, Valentina Dietrich ${ }^{1}$ and Hans-Eike Gäbler ${ }^{2, *}$ \\ 1 Department of Geological Sciences and Applied Geophysics, Montanuniversität Leoben, \\ 8700 Leoben, Austria; frank.melcher@unileoben.ac.at (F.M.); valentina.dietrich@unileoben.ac.at (V.D.) \\ 2 Federal Institute for Geosciences and Natural Resources (BGR), 30655 Hannover, Germany \\ * Correspondence: hans-eike.gaebler@bgr.de
}

check for

updates

Citation: Melcher, F.; Dietrich, V.; Gäbler, H.-E. Analytical Proof of Origin for Raw Materials. Minerals 2021, 11, 461. https://doi.org/ $10.3390 / \min 11050461$

Academic Editor: Antonio Simonetti

Received: 11 March 2021

Accepted: 23 April 2021

Published: 27 April 2021

Publisher's Note: MDPI stays neutral with regard to jurisdictional claims in published maps and institutional affiliations.

Copyright: (C) 2021 by the authors. Licensee MDPI, Basel, Switzerland. This article is an open access article distributed under the terms and conditions of the Creative Commons Attribution (CC BY) license (https:// creativecommons.org/licenses/by/ $4.0 /)$.

\begin{abstract}
Growing public interest in getting information on the origin of raw materials used to manufacture goods for daily life has triggered the development of concepts to increase the transparency of raw material supply chains. Analytical proofs of origin (APOs) for raw materials may support those transparency concepts by giving evidence about the origin of a specific raw material shipment. For a variety of raw materials like gemstones, TTT (tantalum, tin, tungsten) minerals, and others, APOs have been developed. The identification of features that distinguish different origins, databases of those features from reliable reference samples, and a data evaluation strategy adopted to the envisaged application scenario are the key aspects of APO methods. Here, an overview is given on APO methods developed for different raw materials and application cases.
\end{abstract}

Keywords: analytical proof of origin; raw materials; review

\section{Introduction}

Raw material supply chains are complex. They build on the presence of economically mineable mineral commodities that undergo several steps until they are finally used in or as consumer products. Common steps along the supply chain include a pre-mining stage with exploration, a mining stage with excavation and beneficiation, and a postmining stage with processing steps. Along the supply chain, raw materials are transported and traded. Trustworthiness into the transparency of a supply chain is of increasing importance, both to upstream and downstream companies. Any deviation from bestpractice and quality standards in mining, processing, and production is critically looked at by consumers. Therefore, certification concepts have emerged within the past 20 years, aiming at providing transparency to supply chains [1,2]. Such concepts have been and will be developed for several raw materials [2,3]. Recently, an overarching certification system for all raw materials called CERA4in1 was initiated [4]. Transparency in the supply chain may be achieved at all intermediate steps using different approaches $[5,6]$. However, reliable and tamper-proof methods need to be available in those cases, where illegal activities come into play. These include conflict minerals, theft, fraud, smuggling, and others. Safety regulations (e.g., radioactive materials) may also require increased transparency. Reliable methods need to focus on measurable material properties such as composition. Such methods have been developed for some raw materials, e.g., platinum ores, the conflict minerals coltan, cassiterite, wolframite, gold, or precious stones.

Forensic geoscience/geology deals with evidence used in forensic science/criminalistics derived from the analysis of soils, rocks, minerals, and other inorganic materials $[7,8]$. On the other hand, the term geochemical fingerprinting is used to trace down the origin, formation, and/or environmental conditions under which a geological unit has formed in geological time scales $[9,10]$. Methods based on material analysis supporting raw material supply chains' transparency are often based on both forensic geology and geochemical fingerprinting. 
The aim of this work is to review methods and fields of application which (may) provide an additional material analysis-based tool to demonstrate or increase the transparency of raw material supply chains.

\section{The Analytical Proof of Origin (APO)}

The analytical proof of origin (APO) is regarded as an appropriate term to describe analytical methods combined with data evaluation procedures developed to trace materials back to their source(s). An analytical proof of origin investigates the origin of a material from a specific location (mine site, processing plant, metallurgical plant) using measurable and quantifiable material properties. It is based on comparison of a sample in question with reference samples of known origin stored in a database. Generally, such a comparison is done using data plots and/or mathematical/statistical algorithms. In geology, this origin is usually an ore body of restricted size; in processing, the "origin" is a certain step within the processing chain.

Analytical proof of origin methods for raw materials are successfully applied under the following assumptions: (1) minerals have measurable compositions/properties which differ depending on their genesis; (2) minerals from an area of enrichment (orebody) are more closely related to each other than to the same mineral from a second zone of enrichment, e.g., a different ore body.

A large variety of analytical methods available in natural sciences are used for geochemical fingerprinting and forensic geosciences. A meaningful combination of analytical methods with proper data evaluation enable us to decipher processes and, ideally, origin. Such parameters include:

- Geochemistry: major and trace elements; stable, radiogenic, and cosmogenic isotopes;

- Mineralogy: mineralogical composition of a rock, concentrate, or soil sample; quantitative mineralogy, fluid inclusions, and mineral inclusions;

- Crystallography, e.g., characteristic bands in Raman or FTIR spectroscopy;

- Color, e.g., soil color, mineral color;

- Grain properties, e.g., size, shape, sphericity, grain size distribution in a sample, intergrowth with other minerals, grain boundaries;

- Geophysical properties, e.g., magnetic susceptibility, electrical conductivity.

In geological fingerprint applications, geochemistry is the most widely used parameter, offering a large number of different sub-parameters (element concentrations, isotope ratios, element ratios). For later statistical treatment it is important to have in mind that some of them may be interdependent. A good example is the perfect correlation of major elements in whole rock samples (e.g., Si and Fe in a banded iron formations) or in minerals (e.g., Fe and $\mathrm{Mg}$ in olivine). Combinations of geochemical data with crystallographic data (e.g., Raman bands) or grain properties including modal analysis are most promising in certain cases like the investigation of diamonds. A sound statistical evaluation of the dataset is of the utmost importance.

After gaining meaningful data which characterize samples obtained from different origins, a data evaluation step has to be carried out in APO. This step depends on the nature of the obtained data, the raw material, and the question which has to be evaluated using APO. Possible questions which are evaluated using APO are:

- Where does a sample in question come from?

- Is the documented origin of a shipment credible?

- Which of a (low number) of possible origins is the most probable?

Therefore, these data evaluation steps are manifold and include among others:

- The detection of the presence of indicative parameters like origin-characteristic inclusions in colored gem stones;

- $\quad$ Binary and ternary diagrams where different areas are indicative for different origins; 
- Multivariate statistical tools like principal component analysis (PCA) and cluster analysis for grouping of samples and assigning a sample in question to a distinct group (origin);

- Comparison of populations to evaluate the similarity of a sample in question and a reference sample;

- Likelihood ratio concept for hypothesis testing;

- Machine learning algorithms for provenance analysis.

Other important issues for an APO are to evaluate the variability of the discriminating parameters in the source and to have in mind that if a sample in question and a related reference sample originate from an inhomogeneous (e.g., zoned) ore body, special attention should be drawn to the statistical evaluation tools in terms of being applicable in this situation. In particular, evaluation tools which use tabulated decision criteria/critical values (e.g., Kolmogorov-Smirnov test, Wilcoxon's rank sum test, Kruskal-Wallis test) assume that both samples are independent observations that are representative of a single underlying population [11]. This assumption is often not met, e.g., if both samples are obtained from different zones of an ore body during the progress of mining operations. Here, both samples may contain different concentration levels or compositions which would entail that both samples are regarded as not originating from the same ore body if tabulated decision criteria are applied, although they do. The reason for this is that the decision criteria have been developed/calculated under the above mentioned assumption. This false negative result is problematic if APO is applied to evaluate whether a documented origin of a shipment is plausible or not. Here, a false negative result would accuse a person or a company falsely, which could induce serious consequences for the person or company although the declaration was correct. This is different to the situation usually found in typical forensic cases where false positive rates (e.g., a piece of glass found on the clothes of a suspect is erroneously recognized to originate from a broken glass of a crime scene) have to be minimized. In these kinds of APO applications, false negative rates have to be minimized at the expense of false positive results to make a conservative statement. Therefore, if violations of the assumptions of a given statistical tool are accepted, it has to be checked whether this fosters a conservative decision or not. Empirically deduced decision criteria which reflect biased sampling conditions may be applied to solve this problem.

\section{APO for Different Materials}

Analytical proofs of origin have been developed for a variety of raw materials using different analytical methods and data evaluation tools (Table 1).

\subsection{Coltan, Cassiterite, and Wolframite (3T)}

The analytical fingerprint method (AFP) is an analytical protocol combined with statistical data evaluation that has been developed at the Federal Institute for Geosciences and Natural Resources (BGR, Hannover, Germany) to check a declared origin of coltan, cassiterite, or wolframite (3T) shipments [12-17]. The regional focus of this method is Eastern and Central Africa. Significant volumes of these commodities originate from small-scale, artisanal mining operations [18]. Armed groups finance ongoing civil wars by taxing miners and controlling processing and trade [19]. Mineral concentrates are sold to processors outside of Africa, mainly to Asia (China, Malaysia, Thailand), but also to Germany and the USA [20]. The AFP method was developed to support the Regional Initiative against the Illegal Exploitation of Natural Resources (RINR) fostered by the International Conference on the Great Lakes Region (ICGLR). One central analytical laboratory, several local sample preparation laboratories, and a data evaluation unit were set up within the ICGLR region. Here, traded materials can be analyzed to provide additional credibility to document-based traceability systems with due diligence concepts for raw material supply chains. In the AFP approach, samples are tested using appropriate analytical methods together with data evaluation procedures specifically developed for 3T ore concentrates [15-17]. The data evaluation step is based on the comparison of a sample 
in question to samples of known origins stored in a database. The AFP method includes the following steps:

- (Witnessed) sampling of ore concentrates;

- Preparation of polished sections;

- Mineral identification using scanning electron microscopy combined with mineral liberation analysis (SEM-MLA);

- Determination of major and trace element compositions using laser ablation-inductively coupled plasma-mass spectrometry (LA-ICP-MS) on about 50 single grains of the ore minerals;

- Evaluation of chemical data using applied statistics.

A match between a sample in question and a reference sample from the mine site declared as the origin of the sample is looked for using statistical methods. Data from reference samples from many mine sites are stored in a database and are used to evaluate distinct sample properties necessary for statistical testing [15-17]. For AFP, the database of raw material from producing mines is of the utmost importance. Within a period of about 10 years, several hundred samples from producers in Central and Eastern Africa were collected. Additional samples from Ta, Sn, and W ore deposits all around the globe were also included [21,22].

Case studies for the application of the AFP method are given in detail for coltan and cassiterite in Gäbler et al. [15] and for wolframite in Martyna et al. [17]. In the coltan case study, four coltan ore concentrates were obtained from the same mine site (a single elongated pegmatite) at two different dates. For each sample, concentration data for a maximum of 42 elements in about 50 coltan grains were available. If an element showed concentrations below the respective detection limit for more than $30 \%$ of the analyzed grains, this element was not used for data evaluation. Two different data evaluation approaches were applied, namely the "KS-D approach" and the "likelihood ratio approach". Both data evaluation approaches were designed to provide evidence whether the declared origin of a sample in question is plausible or not. In the KS-D approach, element-specific empirical distribution functions are calculated for the sample in question and the reference sample. For each element, the maximum distance between the two distribution functions (Kolmogorov-Smirnov distance) is computed and the median from all element-specific distances is calculated. This median is used to evaluate whether the sample in question and the respective reference sample originate from the same source. For the evaluation of this median, an empirically deduced decision criterion is applied. If more than four reference samples from the declared mine site are available, a deposit-specific decision criterion is calculated from all possible two-sample comparisons of reference samples from this deposit. If the database does not contain enough reference samples from the declared mine site, all possible two-sample comparisons of other reference samples from a common mine site are used. In the coltan case study, all possible two sample comparisons from the studied mine site were correctly regarded as coming from the same mine site, which corresponded to a false negative rate of $0 \%$. However, between $43 \%$ and $65 \%$ of the other samples from the database would erroneously be recognized as coming from the studied mine site if they were compared to reference samples from this mine site. This high rate of false positive results is attributed to the fact that, in this case, a deposit-specific decision criterion was not applied. In the cassiterite case study where a deposit-specific decision criterion could be applied, the false positive rates were between $11 \%$ and $21 \%$, while keeping the false negative rates at $0 \%$.

In the wolframite case study detailed in Martyna et al. [17] five samples from the trading chain with reliable source documents were evaluated. In this case, nine reference samples from the mine site declared as the origin of the samples were available. An "area ratio approach" and a "likelihood ratio approach" were applied for statistical data evaluation. Both approaches were developed in the framework of the likelihood ratio concept for hypothesis testing [23,24], where two competing hypotheses $\left(\mathrm{H}_{1}\right.$ - two samples come from the same source, and $\mathrm{H}_{2}$-two samples come from different sources) were 
evaluated. The two samples were the sample in question and a reference sample from the declared mine site. The probability that $\mathrm{H}_{1}$ was true and the probability that $\mathrm{H}_{2}$ was true were juxtaposed. To obtain these probabilities, a parameter $(\Delta K S D$, see [17]) was calculated, which represents the similarity of the two samples. From the database, numerous sample pairs of samples from the same source and samples from different sources were randomly selected and used to calculate distributions of this parameter for the "same source" case and the "different source" case. These distributions were used to evaluate a given twosample comparison and the probabilities of both hypotheses. These probabilities enabled the researchers to estimate how strongly each hypothesis was supported. In the wolframite case study, $5 * 9=45$ comparisons of the samples in question (samples from the trading chain) to the reference samples could be calculated, and in all cases, $\mathrm{H}_{1}$ was supported strongly with both applied data evaluation approaches. On the other hand, 45 randomly selected comparisons of samples from different sources were computed as well with both approaches, and resulted in the majority of the cases in strong support of $\mathrm{H}_{2}$. If for some comparisons of samples from different sources $\mathrm{H}_{1}$ was erroneously supported, this was done only weakly.

Additionally, predictive methods have also been tested successfully. These tackle those cases in which the origin of a sample can be predicted if it is not represented in the database. In the case of coltan from Central Africa, machine learning algorithms (e.g., linear programming boosting and support vector machines) were applied to attribute unknowns to one of two classes, namely "Congo" and "not Congo". A 85\% probability was reached that a sample from Congo was correctly classified [25].

Harmon et al. [26] and Hark et al. [27] tested laser induced breakdown spectroscopy (LIBS) for APO of coltan. The method was based on the comparison of analytical spectra reflecting chemical composition data. The LIBS method combined with partial least-square discriminant analysis (PLSDA) offers a less expensive and less time-consuming method of sample discrimination. Correct classifications at success levels above $90 \%$ could be achieved for test samples from 37 locations around the world. However, it needs to be discovered how this approach deals with the situation in which samples from shipments along the trading chain are not independent observations that are representative of a single underlying population, which means the heterogeneity of samples obtained from the same mine has to be taken into account. This variability is caused by the facts that (1) pegmatites or quartz veins are not homogeneous ore bodies per se, (2) the different skills of artisanal miners in producing ore concentrates result in samples of variable mineralogical composition, and (3) the mining progress over time on the same mine site may result in additional variability.

\subsection{Platinum Group Elements-Bearing Products of Mining and Metallurgical Operations}

A method called "complex procedure for establishing the nature and source of origin of precious metal-bearing products of mining and metallurgical operations" (CIP) was developed in Russia for the source determination of stolen material containing platinum group elements (PGE) [28]. A significant amount of PGE-bearing material from Russian and South African production sites is illegally supplied to refineries worldwide for further processing. These two countries produce over $80 \%$ of the intermediate PGE-bearing material.

The CIP involves a variety of chemical and mineralogical techniques (microscopy, inductively coupled plasma-optical emission spectroscopy (ICP-OES), inductively coupled plasma-mass spectrometry (ICP-MS), X-ray diffraction (XRD), and scanning electron microscopy with energy-dispersive $X$-ray analysis (SEM-EDX)), and a database where analytical data for different PGE-bearing product types are stored as references. The database is used for the comparison of the samples in question. In the first step, the bulk elemental composition and XRD results of samples in question are compared to data from a database using previously defined threshold values for different elements and phases to identify "suspicious samples" and PGM-bearing products of different producers. The first idea of the composition of a mixture of several intermediate products can be obtained by using 
an algorithm which matches the signature of a sample in question with superimposed signatures of individual components stored in the database. However, for many mixtures of PGM-bearing products, the bulk elemental composition is not sufficient for the identification of the individual components. Therefore, for each product type, several characteristic artificial phases (called pseudo-phases) are defined, and their relative abundances are determined on the basis of a kind of automated mineralogy using SEM-EDX. With this additional information for individual PGM-bearing products, the components of mixtures can be identified [28]. The European Network of Forensic Science Institutes (ENFSI) validated the method in 2008 [29]. The Forensic Review Board concluded that the methodology is regarded as fit for purpose and well-suited for the identification and source attribution of Russian PGE-bearing materials. For worldwide use, the database should be expanded to include information on products from all or most of the producers worldwide.

\subsection{Gold}

Gold is one of the commodities that has a long history in fingerprinting, mainly based on the interest in archeology (e.g., [30,31]). An extensive review on existing methods for gold analysis was presented by Hruschka et al. [32]. It appears that analysis of trace elements by LA-ICP-MS combined with the determination of $\mathrm{Cu}, \mathrm{Ag}$, and probably $\mathrm{Pb}$ isotopes, respectively, provides the best results (M. Brauns, Curt-Engelhorn-Zentrum Archäometrie, oral comm.).

A pilot study on fingerprinting gold from artisanal and small-scale mining was carried out by BRGM [33] with samples from French Guiana and Surinam. The study was based on 28 samples (gold concentrates, "doré", and "galette" gold bars) from 12 different locations (7 French Guiana, 5 Suriname). A combination of relatively easy-to-use analytical tools, ranging from ore microscopy to the investigation of gold grain inclusions and the analysis of the chemical composition of gold grains, was able to distinguish the nature and the geographical origin of gold concentrates in a satisfactory manner. More sophisticated techniques like $\mathrm{Ag}$ and $\mathrm{Cu}$ isotopic analysis can be used to exclude specific sources [33].

Ag concentrations in gold grains can be analyzed by a portable handheld LIBS device [34]. Gold concentrates from five alluvial gold deposits in French Guiana showed different levels and distributions of their gold grain's Ag concentrations [34]. If this approach is followed in the future in terms of analyzing more locations and investigating the variability of the site-specific distributions over time, this approach could be developed to a valuable on-site tool for gold traceability.

Australia and South Africa have established databases for reference materials of mined and processed gold since the 1990s. The government of South Africa passed the "Precious Metals Act, 2005" [35]. Every six months, each licensed gold producer needs to submit a representative sample from different stages of production (native gold and doré) to the Forensic Science Laboratory (FSL) of the South African police services. This is analyzed by ICP-OES (major elements) and LA-ICP-MS (trace elements). According to Dixon [36], the majority of samples stored in the South African gold database consist of drillings from doré gold bars, which are the product of mining activity at a single shaft or several shafts, mining the same reef and supplying a smelter on site. This unrefined gold is representative of the mineralization, type of extraction, and original compositional variation. A large number of prills were supplied by Gold Fields, forming an important dataset in the gold database. Each mine needs to supply raw gold and processed gold (bar, bullion, amalgamated button). However, as pointed out by Dixon [36], the identification of stolen gold based on the sample analysis, in comparison with the above mentioned database, and utilizing additional information from mine security and the police, is a complex process. Different possible ore beneficiation processes and steps may modify the chemical signature of seized illegal samples. Good knowledge of ore deposit mineralogy and ore beneficiation processes is necessary to assist in criminal investigations when the results of geochemical analysis are taken into account. 
Roberts et al. [37] investigated the chemical composition of 858 different gold samples (jewelry alloys, jewelry, mine bullions and suspects from illegal origin). Mine bullions contain elevated amounts of $\mathrm{Pb}$ and can thus be distinguished from jewelry and jewelry alloys which do not show those $\mathrm{Pb}$ concentrations. The commercial alloys are much more consistent in their composition than jewelry. Older jewelry contains elements that are no longer commonly used. Illegal material, according to South African law, can be identified by high levels of $\mathrm{Sn}$, low but measurable levels of $\mathrm{Pb}$, and the presence of $\mathrm{Hg}$. Crude ore processing and metal beneficiation like amalgamation and low-temperature smelting cause these typical features of material that is illegal according to South African law [37].

Since 1994, element associations in gold samples analyzed by LA-ICP-MS have been used to identify the provenance of stolen gold [38,39]. In these studies, a direct visual comparison of raw spectral data, computerized comparison of raw count data, principal component analysis (PCA), and linear discriminant analysis (LDA) were applied to compare the sample in question to a number $(<10)$ of possible sources [40].

\subsection{Diamonds}

Due to their immense value, rarity, and associated conflict problems ("blood diamonds"), diamond fingerprinting is of high interest to the public. Although an international certification system is in place (Kimberley process), it is known that the diamond trade is still far from being transparent. On the other hand, diamond is almost pure carbon with very little impurities; it is the hardest natural substance on Earth, and thus very difficult to handle using classical methods of sample preparation. Discrimination of diamonds using physical and chemical methods has been undertaken since the 1970s [41,42]. So far, cathodoluminescence microscopy, nitrogen and trace element analysis by instrumental neutron activation analysis (INAA), and LA-ICP-MS have been applied $[39,43,44]$. The chemical composition of associated or included "diamond indicator minerals" (e.g., garnet, spinel, pyroxene) may also be used as a vector towards the source of the diamond [43].

The first paper providing statistically robust forensic data for diamond discrimination by Dalpé et al. [45] concluded that much more work is needed to validate the results, which were positive in general. However, all these studies focused on kimberlitic diamonds and avoided alluvial diamonds. Coney et al. [44] proposed a two-stage approach addressing physical and chemical characteristics of diamonds from both kimberlitic and alluvial sources. Morphological features were investigated using a stereomicroscope. Nitrogen concentrations and the aggregation state were determined using infrared spectrometry (FTIR spectrometry). LA-ICP-MS was used for trace element analysis using a doped multielement glucose pellet as a matrix-matched standard. The analytical results of diamond parcels representing 10 sources in Africa showed that discrimination based on one parameter alone does not work. Furthermore, trace element concentrations are often close to or below the mean detection limit of the method used. Subtle differences between sources have become evident, but discrimination is highly complex. For diamonds, the heterogeneity of compositions encountered in the sources, and the difficulties in receiving material that can be used to establish a large database are both regarded as major challenges. Brill et al. [46] reported a case where diamond sets that were suspect to have origins in the Central African Republic (CAR) were compared to diamonds previously analyzed as originating from CAR and the Democratic Republic of the Congo (DRC). Sample morphology, FTIR, and LA-ICP-MS combined with descriptive statistics were applied. It is recommended that for such a task, many stones from one set $(>50)$ should be analyzed and the need for a comprehensive database of diamond data is highlighted.

A pilot study on the multivariate analysis of LIBS spectra obtained from natural and synthetic diamonds suggested that diamond provenance can be determined using this technique [47]. The study was based on 14 sets of 30 diamonds from 12 different natural localities from all over the world and 2 sets of synthetic diamonds of different origins. From each stone, 64 LIBS spectra were obtained and accumulated into 8 spectra per stone. After a normalization step, two data evaluation approaches were applied: (i) unsupervised 
cluster analysis using a leave-one-out approach for validation, and (ii) a train (using $83 \%$ of all spectra) and validate (using 17\% of all spectra) decision tree approach based on a series of partial least-square-regression (PLSR) models. Success rates of $>95 \%$ were reported for both models. Additionally, the heterogeneity within the sets of diamonds and its impact on diamond provenance determination was studied using principal component analysis (PCA) [47].

\subsection{Colored Gemstones}

The origin of high-value colored gemstones is of increasing importance for jewelry trade, as the origin of a gemstone can be considered as a value-determining factor and may influence the salability of a stone [48]. Analytical methods used in geographic origin determination of gemstones were reviewed by Groat et al. [48]. Various parameters starting from basic physical properties like refractive index and specific gravity over the characteristics of inclusions and spectroscopic characteristics up to trace element chemistry and isotope ratios were monitored. Experienced gemologists evaluate the observations and work out an origin call using databases of reference samples. However, sometimes the properties are quite similar, so a definitive origin call is not always possible.

Giuliani et al. [49] analyzed 249 samples of natural ruby and sapphire from 106 deposits in 26 countries. The samples were grouped into three types: primary deposits, secondary deposits, and heated crystals. Oxygen isotope analyses were carried out using the laser-fluorination technique. In combination with gemological properties, it was possible to distinguish ruby and sapphire from different deposits worldwide. Trace element chemistry and isotope ratios are used frequently to determine the geographic origin of ruby and sapphire using binary or ternary discriminating plots or multivariate linear discriminant analysis (LDA) based on various analytical tools like LA-ICP-MS, portable $X$-ray fluorescence (XRF), energy-dispersive XRF (EDXRF), and thermal ionization mass spectrometry (TIMS) [50-53]. Besides trace element chemistry, UV-Vis-NIR spectroscopy, Raman spectroscopy, and the study of inclusion scenes are additional tools to determine the origin of blue sapphire [54]. For rubies, trace element chemistry and the inclusion scenes are of importance for origin determination [55]. However, due to significant overlap in the data of stones from different locations, origin determination for blue sapphires and rubies is sometimes difficult, and thus not always possible [54,55].

Abduriyim and Kitawaki [56] studied 111 emeralds from eight locations worldwide by LA-ICP-MS. Laser ablation was done in the shape of a logo to indicate that this stone was already analyzed by this technique. Binary and ternary diagrams were used to discriminate emerald origins. All localities could be separated; however, not all major emerald sources were covered by this study. For additional confidence, Abduriyim and Kitawaki [56] recommended to support the chemical data by optical properties and internal characteristics. Wang and Krzemnicki [57] used a time-of-flight mass filter in LA-ICP-MS that allowed them to analyze the whole mass spectrum from ${ }^{7} \mathrm{Li}$ to ${ }^{238} \mathrm{U}$ simultaneously, without the need to establish a list of elements prior to analysis, as is the case when using a quadrupole mass filter. Combined with multivariate cluster analysis using t-distributed stochastic neighbor embedding ( $\mathrm{t}-\mathrm{SNE}$ ), they were able to create clusters which coincided with the geographic provenance of emeralds. A combination of UV-Vis-NIR spectroscopy, the study of inclusions, and trace element chemistry data obtained by LA-ICP-MS is used by the Gemological Institute of America (GIA) to determine the origin of emeralds from all over the world [58]. Various trace element plots are used to evaluate the LA-ICP-MS data. Aurisicchio et al. [59] applied electron probe micro analysis (EPMA) and secondary ion mass spectrometry (SIMS) for the analysis of emeralds. They could carry out provenance analysis of these gem stones from all over the world using binary/ternary diagrams and PCA.

The oxygen isotope analysis has also been used for the determination of the origin of emeralds since the 1990s. The $\delta^{18} \mathrm{O}$-value appears to be a good criterion to indicate the origin of exceptional-quality emeralds from Colombia, Afghanistan, Pakistan, Brazil 
(Santa Terezinha de Goiás and Quadrilatero Ferrifero deposits), and Zimbabwe, while the $\delta^{18} \mathrm{O}$-ranges from other origins like Russia, Brazil (Carnaíba and Socotó deposits), Madagascar, and Zambia overlap [60].

The origin of gem-quality tourmaline can be determined by trace element chemistry analyzed by LA-ICP-MS [61,62]. Binary and ternary diagrams are used to separate stones from Nigeria, Brazil, and Mozambique.

Demantoid garnets from six countries have been analyzed by LA-ICP-MS for origin determination [63]. Different multivariate classification models based on PCA-LDA have been studied resulting in a separation of five out of the six countries of origin. It is pointed out that the natural variability has to be taken into account, which makes it necessary to analyze many gems from the same location to apply this tool successfully.

Trace element chemistry obtained by LA-ICP-MS is the most important feature to determine the origin of alexandrite. Secondary factors are inclusions and color-change behavior, which can be visually observed under daylight and incandescent lightning conditions [64].

\subsection{Uranium Ores and Products}

Due to nuclear security issues, knowing the origin of uranium-bearing materials is important. Švedkauskaitè-LeGore et al. [65] demonstrated the usefulness of a combined approach determining $\mathrm{Pb}$ isotopes by multi-collector ICP-MS (MC-ICP-MS) and trace elements by ICP-MS (66 variables). The results from a set of 35 uranium ore samples and 10 yellow cake samples were evaluated using cluster analysis. It was concluded that a combination of impurity and lead isotope measurements is recommended as a highly characteristic fingerprint for nuclear forensic purposes. In another study focusing on uranium ore from three Australian mines, the concentrations of 40 elements and their $\mathrm{Pb}$ isotopic compositions were determined and subsequently treated using PCA [66]. The export products from the operating mines can be clearly distinguished using elemental and isotopic profiles. Chondrite-normalized rare earth element (REE) patterns can be used to distinguish between different uranium ore deposits $[67,68]$. Spano et al. [69] introduced a forensic tool to identify the uranium ore deposit type of an unknown sample. This tool is based on the comparison of the shapes of normalized REE patterns. The sample in question was compared to the reference samples from different uranium ore types. The degree of similarity was quantified using the slope and the correlation coefficient of a linear regression approach. The formation age of uranium ore deposits differs significantly, which allows for researchers to use the $\mathrm{Pb}$ isotope composition to identify or confirm the origin of uranium ore samples [70]. Recently, Corcoran et al. [71] presented a combination of geochemistry, isotopic composition, and mineralogy using PCA to separate different uranium ore deposit types, which can be used as an APO if applied to an uranium ore sample in question.

Sirven et al. [72] investigated the potential of the LIBS technique to identify the origin of 11 yellow cake samples. PCA and soft independent modeling of class analogy (SIMCA) were applied. The SIMCA resulted in a correct identification of all classes. However, in this study, each class consisted of only one sample, so that the inhomogeneity of natural samples was not taken into account, which might influence the classification results substantially.

In addition to the above mentioned methods, determination of the oxygen isotope composition in uranium minerals offers a potential for source discrimination [73]. The $\delta^{18} \mathrm{O}$ values range from -32 to $+11 \%$, and are related to the geological setting unique to each deposit.

\subsection{Base Metals}

Machault et al. [74] proposed to establish so-called identity cards for ore deposits to increase transparency in raw material supply chains. These identity cards contain mineralogical and microtextural parameters which record the unique signature of an ore deposit (mineralogical composition, microtextures of target minerals, "pseudo-paragenetic 
sequence", chemical composition and distribution of target minerals, and "memory loss" of metals during mineral processing). At the stage of the ore concentrates, not only the origin of the ore, but also the kind of ore processing applied determines the ore concentrate characteristics as well. Therefore, the "memory loss" during mineral processing should be taken into account. An example for setting up identity cards for nine different volcanic massive sulphide ore deposits from two metallogenic provinces (Iberian Pyrite Belt, Ural) was given by Machault et al. [74]. According to Machault et al. [74] the main challenge which has to be addressed in establishing an ore identify card is to take ore variability into account and obtain samples that are the most representative of a deposit.

The rapid development of LA-ICP-MS techniques in the past decade has opened opportunities for the APO of base metal ores, because the main metal phases sphalerite, chalcopyrite, galena, pyrite, and pyrrhotine are carriers of a large number of trace elements [75]. In addition to research devoted to problems of trace element substitution in minerals, processes governing trace element incorporation in sulphides, and their probable liberation from such ores, datasets, and some databases have been developed that are of potential use for APO [76]. After having defined a question to be evaluated by APO, these data can be used as a starting point for the development of an APO in this field.

Similar trace element analysis routines are increasingly applied to magnetite and other iron oxides. Such methods also discriminate between genetic ore types, ore provinces, and different ore bodies [77].

\subsection{Heterogenite}

Heterogenite is a trade name for Co ore concentrates produced in Katanga/DR Congo, and also the name of a mineral with a $\mathrm{CoOOH}$ composition. Cobalt is regarded as a critical raw material by the European Union [78]. About $60 \%$ of the world supply originates from the Democratic Republic of the Congo, and an additional 2\% from adjacent Zambia [79]. At present, cobalt is preferably, but not exclusively, mined from heterogenite ore.

The TRACE project financed by the Belgian Federal Public Service for the Pro Sciences Policy investigated methods to trace heterogenite [80]. Various analytical methods (Raman microspectroscopy, EPMA, electron backscatter diffraction, SEM, ICP-MS, and LA-ICP-MS) have been used to characterize the mineral and to identify differences in the chemical composition and structural state between different deposits in Katanga [81,82]. It was demonstrated that heterogenite may be dated using U-Pb isotopes [83] and that it shows a range of chemical compositions and structural states. However, a conclusive methodology based on a large set of data proving that the provenance determination of heterogenite from different mine sites in Katanga is possible has not yet been published. Application to a real analytical proof of origin scenario could not be convincingly demonstrated.

\subsection{Phosphate Raw Materials}

Phosphorous, as one of the three major macronutrients, is essential for all life, and therefore indispensable for food production. It is obtained from phosphate rocks of sedimentary and igneous origin. Europe's import dependency is almost $100 \%$ of the demand, and supply security is a major issue [84]. Some of the raw materials, however, carry hazardous elements such as uranium or cadmium, in concentrations higher than those tolerated by law. These trace elements would accumulate in soil if fertilizer produced from such raw materials were used. Sattouf et al. [85] used isotope ratio measurements of $U$ and Sr to identify the origin of rock phosphates and fertilizers. Four main geographic origins, the USA, the Middle East and North Africa, the Russian Kola Peninsula, and Senegal and Togo, can be distinguished using a combination of $\mathrm{U}$ and $\mathrm{Sr}$ isotope ratios.

\subsection{Vermiculite}

Vermiculite is an industrial mineral with excellent insulating and absorption properties, finding extensive use in construction, insulation, packing materials, and gardening adjuncts. However, in some vermiculite products, asbestiform minerals have been identi- 
fied. A clear correlation was made between asbestos content in vermiculite and cases of lung disease in Libby, Montana, where vermiculite has been mined for a long period of time [86]. The Idaho National Laboratory used geochemical signatures to determine the origin of commercially available vermiculite. A total of 44 bulk samples from different origins was analyzed for 10 major elements by XRF and for 28 trace elements, including REE, by neutron activation analysis (NAA). The analyses were carried out on homogenized bulk samples without previous mineral separation or cleaning; no attempt was made to use mineralogical criteria for discrimination. It was shown that the REE was especially highly diagnostic in provenance determination. Statistical analysis of the data formed the main part of the study. Following basic data description using probability plots and correlation matrices, advanced statistical methods such as hierarchical cluster analysis, K-cluster analysis, and discriminant analysis using different models were carried out to identify samples from an unknown origin. Discriminant analysis allowed for a clear differentiation between the primary suppliers of vermiculite to the United States; therefore, this technique can be used to determine the relative risk of asbestos contamination based on the sample origin.

\subsection{Marble}

A method for the provenance analysis of marble used in antique objects was developed at Montanuniversität Leoben [87-90]. The method uses a multivariate approach to locate the provenance of marbles used for antique sculptures. Parameters evaluated include petrography (grain size), stable isotopes $\left(\delta^{13} \mathrm{C}, \delta^{18} \mathrm{O}\right)$, trace elements, and the analysis of fluid inclusions. Data are analyzed using multivariate discrimination methods. The database includes analytical data of more than 3500 quarries from all regions of the Roman Empire. The method has been successfully applied to fingerprint the origin of ancient white marbles from artefacts, e.g., solving the Carrara-Göktepe entanglement [91], provenancing the marbles used to construct the mausoleum of Belevi [88] and many others $[90,92,93]$.

Table 1. Analytical proof of origin for different raw materials.

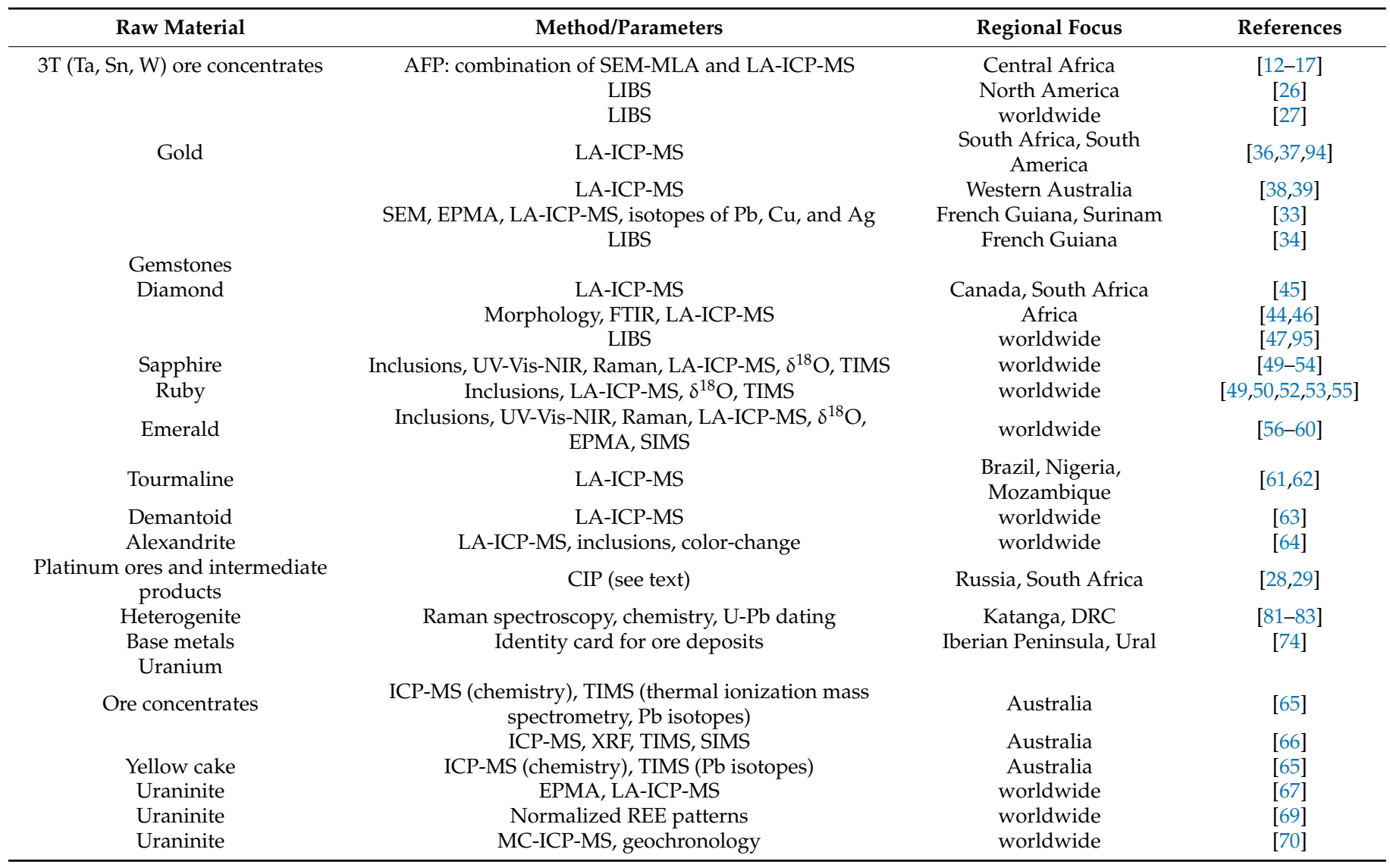


Table 1. Cont.

\begin{tabular}{cccc}
\hline Raw Material & Method/Parameters & Regional Focus & References \\
\hline Uraninite & EPMA, ICP-MS, MC-ICP-MS, powder X-ray & worldwide & worldwide \\
Minerals & diffraction, PCA & worldwide & [71] \\
Phosphate & $\delta^{18} \mathrm{O}$ & worldwide & worldwide \\
Vermiculite & U and Sr isotope ratios & Roman Empire & {$[85]$} \\
Marble & Main and trace element chemistry & [87-93] \\
\hline
\end{tabular}

\section{Conclusions}

For a variety of raw materials, analytical proofs of origin have been developed to support transparency in raw material supply chains, trace back stolen or suspect materials of dubious origins, increase the value of gems on the market, or exclude raw materials carrying hazardous impurities from being widely used. All methods have in common that in the first instance, features have to be identified which distinguish samples from different origins. Trace element chemistry seems to be the most important feature to do this, but it is not always the one and only solution.

In general, a successful application of the distinguishing features for APO requires a database where information about those features from different origins are stored. Therefore, reliable reference samples of known origins are of the utmost importance for every APO approach. However, for some materials (e.g., gold, gemstones) the collection of reference materials is quite challenging because of restricted access to mine sites or safety risks in certain areas.

If distinguishing features have been identified and a suitable database is available, data evaluation has to be done. Data evaluation methods range from experts' experiences (fluid inclusion scenes in gems) over the use of binary or ternary data plots up to more sophisticated statistical data treatments, even at the raw data stage (e.g., LIBS). The rarity and the variability of the distinguishing features in the source, and the question of whether the used samples can be regarded as independent observations that are representative of a single underlying population have to be considered. The latter is especially important when statistical data evaluation methods are applied, which assume that the used samples meet this requirement. If this assumption is violated empirically-deduced decision criteria can be developed.

Self-learning algorithms in discriminant analysis provide criteria to evaluate whether a sample belongs to a certain class (origin), which is used in the data evaluation of APO methods.

Nailing down the question which has to be answered is important to find a suitable data evaluation strategy, e.g., "Where does this sample come from?" or "Is the documented origin of a shipment credible?" or "Which of a (low number) of possible origins is the most probable?". All of the above-mentioned points show that there is no general recommendation for how to set up an APO for a given case. The APO must always be adopted to the envisaged application scenario and the question which has to be answered.

Author Contributions: Conceptualization, methodology, and formal analysis F.M. and H.-E.G.; writing-original draft preparation, F.M., V.D. and H.-E.G.; All authors have read and agreed to the published version of the manuscript.

Funding: Parts of this research have been carried out in the framework of the CERA project (Certification of Raw Materials) funded by EIT Raw Materials. For further information check the project website: www.cera4in1.org (accessed on 5 March 2021).

Acknowledgments: The authors are grateful to the academic editor and two anonymous reviewers for their valuable comments on an earlier version of the manuscript.

Conflicts of Interest: The authors declare no conflict of interest. 


\section{References}

1. OECD. OECD Due Diligence Guidance for Responsible Supply Chains of Minerals from Conflict-Affected and High-Risk Areas, 3rd ed.; OECD Publishing: Paris, France, 2016.

2. Van den Brink, S.; Kleijn, R.; Tukker, A.; Huisman, J. Approaches to responsible sourcing in mineral supply chains. Resour. Conserv. Recycl. 2019, 145, 389-398. [CrossRef]

3. Kickler, K.; Franken, G. Sustainability Schemes for Mineral Resources: A Comparative Overview; Bundesanstalt für Geowissenschaften und Rohstoffe: Hannover, Germany, 2017; p. 167.

4. CERA. The Certification of Raw Materials. Available online: https://www.cera4in1.org/ (accessed on 5 March 2021).

5. Kashmanian, R.M. Building Greater Transparency in Supply Chains to Advance Sustainability. Environ. Qual. Manag. 2017, 26, 73-104. [CrossRef]

6. Cartier, L.E.; Ali, S.H.; Krzemnicki, M.S. Blockchain, Chain of Custody and Trace Elements: An Overview of Tracking and Traceablity Opportunities in the Gem Industry. J. Gemmol. 2018, 36, 16. [CrossRef]

7. Ruffell, A. Forensic pedology, forensic geology, forensic geoscience, geoforensics and soil forensics. Forensic Sci. Int. 2010, 202, 9-12. [CrossRef]

8. Pye, K.; Croft, D.J. (Eds.) Forensic Geoscience: Principles, Techniques and Applications; The Geological Socienty London: London, UK, 2004; Volume 232, p. 328.

9. Hoefs, J. Geochemical fingerprints: A critical appraisal. Eur. J. Mineral. 2010, 22, 3-15. [CrossRef]

10. Kamber, B.S. Geochemical fingerprinting: 40 years of analytical development and real world applications. Appl. Geochem. 2009, 24, 1074-1086. [CrossRef]

11. Gauthier, T.D.; Hawley, M.E. Statistical Methods. In Introduction to Environmental Forensics, 2nd ed.; Murphy, B.L., Robert, D.M., Eds.; Elsevier: Amsterdam, The Netherlands, 2007; pp. 129-183.

12. Melcher, F.; Sitnikova, M.; Graupner, T.; Martin, N.; Oberthür, T.; Henjes-Kunst, F.; Gäbler, E.; Gerdes, A.; Brätz, H.; Davis, D.; et al. Fingerprinting of conflict minerals: Columbite-tantalite ("coltan") ores. Sga News 2008, 23, 7-14.

13. Gäbler, H.-E.; Melcher, F.; Graupner, T.; Bahr, A.; Sitnikova, M.A.; Henjes-Kunst, F.; Oberthür, T.; Brätz, H.; Gerdes, A. Speeding Up the Analytical Workflow for Coltan Fingerprinting by an Integrated Mineral Liberation Analysis/LA-ICP-MS Approach. Geostand. Geoanalytical Res. 2011, 35, 431-448. [CrossRef]

14. Gäbler, H.-E.; Rehder, S.; Bahr, A.; Melcher, F.; Goldmann, S. Cassiterite fingerprinting by LA-ICP-MS. J. Anal. At. Spectrom. 2013, 28, 1247-1255. [CrossRef]

15. Gäbler, H.-E.; Schink, W.; Gawronski, T. Data Evaluation for Cassiterite and Coltan Fingerprinting. Minerals 2020, 10, 926. [CrossRef]

16. Gäbler, H.-E.; Schink, W.; Goldmann, S.; Bahr, A.; Gawronski, T. Analytical Fingerprint of Wolframite Ore Concentrates. J. Forensic Sci. 2017, 62, 881-888. [CrossRef]

17. Martyna, A.; Gäbler, H.-E.; Bahr, A.; Zadora, G. Geochemical wolframite fingerprinting-the likelihood ratio approach for laser ablation ICP-MS data. Anal. Bioanal. Chem. 2018, 410, 3073-3091. [CrossRef] [PubMed]

18. Schütte, P.; Näher, U. Tantalum supply from artisanal and small-scale mining: A mineral economic evaluation of coltan production and trade dynamics in Africa's Great Lakes region. Resour. Policy 2020, 69, 101896. [CrossRef]

19. Young, S.B. Responsible sourcing of metals: Certification approaches for conflict minerals and conflict-free metals. Int. J. Life Cycle Assess. 2018, 23, 1429-1447. [CrossRef]

20. Schütte, P. International mineral trade on the background of due diligence regulation: A case study of tantalum and tin supply chains from East and Central Africa. Resour. Policy 2019, 62, 674-689. [CrossRef]

21. Melcher, F.; Graupner, T.; Gäbler, H.-E.; Sitnikova, M.; Henjes-Kunst, F.; Oberthür, T.; Gerdes, A.; Dewaele, S. Tantalum-(niobiumtin) mineralisation in African pegmatites and rare metal granites: Constraints from $\mathrm{Ta}-\mathrm{Nb}$ oxide mineralogy, geochemistry and U-Pb geochronology. Ore Geol. Rev. 2015, 64, 667-719. [CrossRef]

22. Melcher, F.; Graupner, T.; Gäbler, H.-E.; Sitnikova, M.; Oberthür, T.; Gerdes, A.; Badanina, E.; Chudy, T. Mineralogical and chemical evolution of tantalum-(niobium-tin) mineralisation in pegmatites and granites. Part 2: Worldwide examples (excluding Africa) and an overview of global metallogenetic patterns. Ore Geol. Rev. 2017, 89, 946-987. [CrossRef]

23. Aitken, C.G.G.; Taroni, F. Statistics and the Evaluation of Evidence for Forensic Scientists, 2nd ed.; Wiley: Chichester, UK, 2004.

24. Zadora, G.; Martyna, A.; Ramos, D.; Aitken, C.G.G. Statistical Analysis in Forensic Science Evidential Values of Multivariate Physicochemical Data; Wiley: Chichester, UK, 2014.

25. Savu-Krohn, C.; Rantitsch, G.; Auer, P.; Melcher, F.; Graupner, T. Geochemical Fingerprinting of Coltan Ores by Machine Learning on Uneven Datasets. Nat. Resour. Res. 2011, 20, 177-191. [CrossRef]

26. Harmon, R.S.; Shughrue, K.M.; Remus, J.J.; Wise, M.A.; East, L.J.; Hark, R.R. Can the provenance of the conflict minerals columbite and tantalite be ascertained by laser-induced breakdown spectroscopy? Anal. Bioanal. Chem. 2011, 400, 3377-3382. [CrossRef] [PubMed]

27. Hark, R.; Remus, J.; East, L.; Harmon, R.; Wise, M.; Tansi, B.; Shughrue, K.; Dunsin, K.; Liu, C. Geographical analysis of "conflict minerals" utilizing laser-induced breakdown spectroscopy. Spectrochim. Acta Part B At. Spectrosc. 2012, 74-75, 131-136. [CrossRef]

28. Perelygin, A.; Kuchkin, A.; Kharkov, N.; Moskvina, T. Criminalistic identification of PGM-containing products of mining and metallurgical companies. Forensic Sci. Int. 2008, 174, 12-15. [CrossRef]

29. ENFSI. CIP Project: Report of the CIP Forensic Review Board; ENFSI: The Hague, The Netherlands, $2008 ;$ p. 47. 
30. Hartmann, A. Prähistorische Goldfunde—Spektralanalytische Untersuchungen und deren Auswertung; Gebr. Mann: Berlin, Germany, 1970.

31. Hartmann, A. Prähistorische Goldfunde aus Europa II-Spektralanalytische Untersuchungen und deren Auswertung; Gebr. Mann: Berlin, Germany, 1982.

32. Hruschka, F.; Melcher, F.; Kain-Brückner, B. Analytical Tools to Constrain the Origin of Gold from Conflict-affected and High-Risk Areas. Scoping Stud based on the DR Congo; Technisches Büro für Bergwesen Hruschka \& Lehrstuhl für Geologie und Lagerstättenlehre der Montanuniversität Leoben: Hannover, Germany, 2016; p. 154.

33. Augé, T.; Bailly, L.; Bourbon, P.; Guerrot, C.; Viprey, L.; Telouk, P. Faisabilité Technique d'une Traçabilité Physico-Chimique de L'or de Guyane; BRGM: Orléans, France, 2015; p. 154.

34. Pochon, A.; Desaulty, A.-M.; Bailly, L. Handheld laser-induced breakdown spectroscopy (LIBS) as a fast and easy method to trace gold. J. Anal. At. Spectrom. 2020, 35, 254-264. [CrossRef]

35. Republic of South Africa PRECIOUS METALS ACT, 2005. Gov. Gaz. 2006, 28164, 28.

36. Dixon, R.D. Provenance of Illicit Gold with Emphasis on the Witwatersrand Basin; Department of Geology in the Faculty of Natural and Agricultural Sciences, University of Pretoria: Pretoria, South Africa, 2014; p. 180.

37. Roberts, R.J.; Dixon, R.D.; Merkle, R.K.W. Distinguishing Between Legally and Illegally Produced Gold in South Africa. J. Forensic Sci. 2016, 61, S230-S236. [CrossRef] [PubMed]

38. Watling, R.J.; Herbert, H.K.; Delev, D.; Abell, I.D. Gold fingerprinting by laser ablation inductively coupled plasma mass spectrometry. Spectrochim. Acta Part B At. Spectrosc. 1994, 49, 205-219. [CrossRef]

39. Watling, R.J. Novel Applications of Laser Ablation-Inductively Coupled Plasma Mass Spectrometry in Inorganic Analytical Chemistry. Rapid Commun. Mass Spectrom. 1996, 10, 130-137. [CrossRef]

40. Watling, R.; Scadding, C.; May, C.D. Chemical fingerprinting of gold using laser ablation inductively coupled plasma mass spectrometry (LA-ICP-MS). J. R. Soc. West. Aust. 2014, 97, 87-96.

41. Harris, J.W.; Hawthorne, J.B.; Oosterveld, M.M. Regional and Local Variations in the Characteristics of Diamond from Some Southern African Kimberlites. In Kimberlites, Diatremes, and Diamonds: Their Geology, Petrology, and Geochemistry; Boyd, F.R., Meyer, H.O.A., Eds.; American Geophysical Union: Washington, DC, USA, 1982; pp. 27-41. [CrossRef]

42. Harris, J.W.; Hawthorne, J.B.; Oosterveld, M.M.; Wehmeyer, E. A classification scheme for diamond and a comparative study of South African diamond characteristics. Phys. Chem. Earth 1975, 9, 765-783. [CrossRef]

43. Watling, R.J.; Herbert, H.K.; Barrow, I.S.; Thomas, A.G. Analysis of diamonds and indicator minerals for diamond exploration by laser ablation-inductively coupled plasma mass spectrometry. Analyst 1995, 120, 1357-1364. [CrossRef]

44. Coney, L.; Moila, A.V.; Quadling, A.G. Gem-Quality Diamonds: Source Discrimination. S. Afr. J. Geol. 2012, 115, 33-46. [CrossRef]

45. Dalpé, C.; Hudon, P.; Ballantyne, D.J.; Williams, D.; Marcotte, D. Trace Element Analysis of Rough Diamond by LA-ICP-MS: A Case of Source Discrimination? J. Forensic Sci. 2010, 55, 1443-1456. [CrossRef]

46. Brill, S.; Lilimu, N.; Chetty, D. Diamond fingerprinting for source discrimination using laser ablation inductively coupled plasma mass spectrometry (LA-ICP-MS) and Fourier transform infrared spectrometry (FTIR). Heliyon 2020, 6, e05592. [CrossRef] [PubMed]

47. McManus, C.E.; McMillan, N.J.; Dowe, J.; Bell, J. Diamonds Certify Themselves: Multivariate Statistical Provenance Analysis. Minerals 2020, 10, 916. [CrossRef]

48. Groat, L.A.; Giuliani, G.; Stone-Sundberg, J.; Sun, Z.; Renfro, N.D.; Palke, A.C. A Review of Analytical Methods used in Geographic Origin Determination of Gemstones. Gems Gemol. 2019, 55, 512-535. [CrossRef]

49. Giuliani, G.; Fallick, A.E.; Garnier, V.; France-Lanord, C.; Ohnenstetter, D.; Schwarz, D. Oxygen isotope composition as a tracer for the origins of rubies and sapphires. Geology 2005, 33, 249-252. [CrossRef]

50. Muhlmeister, S.; Fritsch, E.; Shigley, J.E.; Devouard, B.; Laurs, B.M. Separating natural and synthetic rubies on the basis of trace-element chemistry. Gems Gemol. 1998, 34, 22. [CrossRef]

51. Guillong, M.; Günther, D. Quasi ‘non-destructive' laser ablation-inductively coupled plasma-mass spectrometry fingerprinting of sapphires. Spectrochim. Acta Part B 2001, 56, 1219-1231. [CrossRef]

52. Barone, G.; Mazzoleni, P.; Bersani, D.; Raneri, S. Portable XRF: A Tool for the Study of Corundum Gems. Open Archaeol. 2017, 3 , 194-201. [CrossRef]

53. Krebs, M.Y.; Hardman, M.F.; Pearson, D.G.; Luo, Y.; Fagan, A.J.; Sarkar, C. An Evaluation of the Potential for Determination of the Geographic Origin of Ruby and Sapphire Using an Expanded Trace Element Suite Plus Sr-Pb Isotope Compositions. Minerals 2020, 10, 447. [CrossRef]

54. Palke, A.C.; Saeseaw, S.; Renfro, N.D.; Sun, Z.; McClure, S.F. Geographic Origin Determination of Blue Sapphire. Gems Gemol. 2019, 55, 536-579. [CrossRef]

55. Palke, A.C.; Saeseaw, S.; Renfro, N.D.; Sun, Z.; McClure, S.F. Geographic Origin Determination of Ruby. Gems Gemol. 2019, 55, 580-612. [CrossRef]

56. Abduriyim, A.; Kitawaki, H. Applications of laser ablation-inductively coupled plasma-mass spectrometry (LA-ICP-MS) to gemology. Gems Gemol. 2006, 42, 98-118. [CrossRef]

57. Wang, H.A.O.; Krzemnicki, M.S. Multi-element analysis of minerals using laser ablation inductively coupled plasma time of flight mass spectrometry and geochemical data visualization using $\mathrm{t}$-distributed stochastic neighbor embedding: Case study on emeralds. J. Anal. At. Spectrom. 2021, 36, 518-527. [CrossRef] 
58. Saeseaw, S.; Renfro, N.D.; Palke, A.C.; Sun, Z.; McClure, S.F. Geographical Origin Determination of Emerald. Gems Gemol. 2019, 55, 614-646. [CrossRef]

59. Aurisicchio, C.; Conte, A.M.; Medeghini, L.; Ottolini, L.; De Vito, C. Major and trace element geochemistry of emerald from several deposits: Implications for genetic models and classification schemes. Ore Geol. Rev. 2018, 94, 351-366. [CrossRef]

60. Giuliani, G.; France-Lanord, C.; Coget, P.; Schwarz, D.; Cheilletz, A.; Branquet, Y.; Giard, D.; Martin-Izard, A.; Alexandrov, P.; Piat, D.H. Oxygen isotope systematics of emerald: Relevance for its origin and geological significance. Min. Depos. 1998, 33, 513-519. [CrossRef]

61. Abduriyim, A.; Kitawaki, H.; Furuya, M.; Schwarz, D. "Paraíba"-type Copper-bearig Tourmaline from Brazil, Nigeria, and Mozambique: Chemical Fingerprinting by LA-ICP-MS. Gems Gemol. 2006, 42, 4-21. [CrossRef]

62. Katsurada, Y.; Sun, Z.; Breeding, C.M.; Dutrow, B.L. Geographic Origin Determination of Paraíba Tourmaline. Gems Gemol. 2019, 55, 648-659. [CrossRef]

63. Bindereif, S.G.; Rüll, F.; Schwarzinger, S.; Schwarzinger, C. Chemometric Modeling of Trace Element Data for Origin Determination of Demantoid Garnets. Minerals 2020, 10, 1046. [CrossRef]

64. Sun, Z.; Palke, A.C.; Muyal, J.; DeGhionno, D.; McClure, S.F. Geographic Origin Determination of Alexandrite. Gems Gemol. 2019, 55, 660-681. [CrossRef]

65. Švedkauskaite-LeGore, J.; Rasmussen, G.; Abousahl, S.; van Belle, P. Investigation of the sample characteristics needed for the determination of the origin of uranium-bearing materials. J. Radioanal. Nucl. Chem. 2008, 278, 201-209. [CrossRef]

66. Keegan, E.; Richter, S.; Kelly, I.; Wong, H.; Gadd, P.; Kuehn, H.; Alonso-Munoz, A. The provenance of Australian uranium ore concentrates by elemental and isotopic analysis. Appl. Geochem. 2008, 23, 765-777. [CrossRef]

67. Frimmel, H.E.; Schedel, S.; Brätz, H. Uraninite chemistry as forensic tool for provenance analysis. Appl. Geochem. 2014, 48, 104-121. [CrossRef]

68. Varga, Z.; Krajkó, J.; Peńkin, M.; Novák, M.; Eke, Z.; Wallenius, M.; Mayer, K. Identification of uranium signatures relevant for nuclear safeguards and forensics. J. Radioanal. Nucl. Chem. 2017, 312, 639-654. [CrossRef] [PubMed]

69. Spano, T.L.; Simonetti, A.; Wheeler, T.; Carpenter, G.; Freet, D.; Balboni, E.; Dorais, C.; Burns, P.C. A novel nuclear forensic tool involving deposit type normalized rare earth element signatures. Terra Nova 2017, 29, 294-305. [CrossRef]

70. Corcoran, L.; Simonetti, A. Geochronology of Uraninite Revisited. Minerals 2020, 10, 205. [CrossRef]

71. Corcoran, L.; Simonetti, A.; Spano, T.L.; Lewis, S.R.; Dorais, C.; Simonetti, S.; Burns, P.C. Multivariate Analysis Based on Geochemical, Isotopic, and Mineralogical Compositions of Uranium-Rich Samples. Minerals 2019, 9, 537. [CrossRef]

72. Sirven, J.-B.; Pailloux, A.; M’Baye, Y.; Coulon, N.; Alpettaz, T.; Stéphane, G. Towards the determination of the geographical origin of yellow cake samples by laser-induced breakdown spectroscopy and chemometrics. J. Anal. At. Spectrom. 2009, 24, 451-459. [CrossRef]

73. Fayek, M.; Horita, J.; Ripley, E.M. The oxygen isotopic composition of uranium minerals: A review. Ore Geol. Rev. 2011, 41, 1-21. [CrossRef]

74. Machault, J.; Barbanson, L.; Augé, T.; Bailly, L.; Orgeval, J.-J. Mineralogical and microtextural parameters in metals ores traceability studies. Ore Geol. Rev. 2014, 63, 307-327. [CrossRef]

75. Cook, N.J.; Ciobanu, C.L.; Pring, A.; Skinner, W.; Shimizu, M.; Danyushevsky, L.; Saini-Eidukat, B.; Melcher, F. Trace and minor elements in sphalerite: A LA-ICPMS study. Geochim. Cosmochim. Acta 2009, 73, 4761-4791. [CrossRef]

76. Henning, S.; Birkenfelder, S.; Graupner, T.; Franke, H.; Nawothnig, B.; Pursche, K. The new critical metals database "HTMET": High tech trace element characteristics of sulphides from base metal provinces in the Variscan basement and adjacent sedimentary rocks in Germany. Z. Dtsch. Ges. Geowiss. 2019, 170, 161-180. [CrossRef]

77. Dare, S.A.S.; Barnes, S.-J.; Beaudoin, G.; Méric, J.; Boutroy, E.; Potvin-Doucet, C. Trace elements in magnetite as petrogenetic indicators. Min. Depos. 2014, 49, 785-796. [CrossRef]

78. European Commission. Communication from the Commission to the European Parliament, the Council, the European Economic and Social Committee and the Committee of the Regions-Critical Raw Materials Resilience: Charting a Path towards greater Security and Sustainability; European Commission: Brussels, Belgium, 2020. Available online: https://eur-lex.europa.eu/legal-content/EN/TXT/PDF/ ?uri=CELEX:52020DC0474\&from=EN (accessed on 19 February 2021).

79. Reichl, C.; Schatz, M. World Mining Data 2019; Federal Ministry for Sustainability and Tourism: Vienna, Austria, 2019.

80. TRACE: TRACeability of hEterogenite. Available online: https://www.naturalsciences.be/en/science/do/94/scientificresearch/research-projects/project/1035 (accessed on 5 March 2021).

81. Burlet, C.; Vanbrabant, Y.; Goethals, H.; Thys, T.; Dupin, L. Raman spectroscopy as a tool to characterize heterogenite (CoO.OH) (Katanga Province, Democratic Republic of Congo). Spectrochim. Acta. Part A Mol. Biomol. Spectrosc. 2011, 80, 138-147. [CrossRef] [PubMed]

82. Decrée, S.; Pourret, O.; Baele, J.-M. Rare earth element fractionation in heterogenite (CoOOH): Implication for cobalt oxidized ore in the Katanga Copperbelt (Democratic Republic of Congo). J. Geochem. Explor. 2015, 159, 290-301. [CrossRef]

83. Decree, S.; Deloule, É.; De Putter, T.; Dewaele, S.; Mees, F.; Baele, J.-M.; Marignac, C. Dating of U-rich heterogenite: New insights into U deposit genesis and U cycling in the Katanga Copperbelt. Precambrian Res. 2014, 241, 17-28. [CrossRef]

84. Geissler, B.; Mew, M.; Steiner, G. Phosphate supply security for importing countries: Developments and the current situation. Sci. Total Environ. 2019, 677, 511-523. [CrossRef] 
85. Sattouf, M.; Kratz, S.; Diemer, K.; Fleckenstein, J.; Rienitz, O.; Schnug, E. Significance of uranium and strontium isotope ratios for retracing the fate of uranium during the processing of phosphate fertilizers from rock phosphates. In Loads and Fate of Fertilizer Derived Uranium; De Kok, L.J., Schnug, E., Eds.; Backhuys Publishers: Leiden, The Netherlands, 2008; pp. 191-202.

86. Wright, K.E.; Palmer, C.D. Geochemical Signatures as a Tool for Vermiculite Provenance Determination; Idaho National Laboratory: Idaho Falls, ID, USA, 2008; p. 157.

87. Prochaska, W.; Attanasio, D. Tracing the origin of marbles by inclusion fluid chemistry. In Proceedings of the Interdisciplinary Studies on Ancient Stone, IX ASMOSIA Conference 2009, Tarragona, Spain, 8-13 June 2009.

88. Prochaska, W.; Grillo, S.M. A new method for the determination of the provenance of white marbles by chemical analysis of inclusion fluids. The marbles of the mausoleum of Belevi/Turkey. Archaeometry 2010, 52, 59-82. [CrossRef]

89. Prochaska, W. A sculptural marble of prime quality in antiquity-The dolomitic marble of the Sivec mountains in Macedonia. Archaeometry 2013, 55, 179-197. [CrossRef]

90. Attanasio, D.; Bruno, M.; Prochaska, W.; Yavuz, A. The Asiatic marbles of the Hadrian's Villa at Tivoli. J. Archaeol. Sci. 2013, 40, 4358-4368. [CrossRef]

91. Prochaska, W.; Attanasio, D. Multimethod provenance analyses of white marbles—the Carrara-Göktepe entanglement. In Proceedings of the 1. International Conference on Metrology for Archaelogy 2015, Benevento, Italy, 21-23 October 2015; pp. 15-19.

92. Attanasio, D.; Bruno, M.; Prochaska, W. The Docimian Marble of the Ludovisi and Capitoline Gauls and Other Replicas of the Pergamene Dedications. Am. J. Archaeol. 2011, 115, 575-587. [CrossRef]

93. Attanasio, D.; Bruno, M.; Prochaska, W.; Yavuz, A.B. A Multi-Method Database of the Black and White Marbles of Göktepe (Aphrodisias), Including Isotopic, EPR, Trace and Petrographic Data. Archaeometry 2015, 57, 217-245. [CrossRef]

94. Dixon, R.D.; Merkle, R.K.W. Identifying the source of illicit gold from South America. Geol. Soc. Lond. Spec. Publ. $2019,492$. [CrossRef]

95. McManus, C.E.; Dowe, J.; McMillan, N.J. Use of C-C and C-N Molecular Emissions in Laser-Induced Breakdown Spectroscopy Data to Determine Diamond Provenance. Microsc. Microanal. 2017, 23, 2282-2283. [CrossRef] 